\title{
Italy's new "superminister" quells researchers' fears
}

In a move that caught many by surprise, the new center-left Italian government announced in May that it would merge the Ministry of University and Science and Technological Research (MURST) and the Public Education Ministry into one "superministry," to be headed by prominent Democratic Left Party member Luigi Berlinguer, the

former rector of Siena

University.

Many in the research community express concern that the merger of the two large ministries will undermine the strong commitment to research proclaimed by Italy's new Prime Minister Romano Prodi during the election campaign. They fear that the current hot debate over education reform (which involves all lev-

els of Italian The new schooling, from "superminister" kindergarten of Italian education through gradu- and science, ate school) will Luigi Berlinguer. overshadow the urgent need for reorganization of Italian research.

Another worry is over the destiny of an important document drawn up before elections by the "Conferenza dei Rettori" (CRUI), which was to serve as a blueprint for reform. The CRUI document offers seventeen proposals for reworking Italian research based on an American entrepreneurial model, including profit-sharing on patents and creation of small "hightechnology" businesses based on close collaboration between academia and industry. Some believe that a leftist minister like Berlinguer will not be open to such market-driven proposals as those called for by the CRUI document.

However, in an extensive interview with Nature Medicine, Berlinguer tried to allay all the fears. He says that by "opting for a superministry, Italy followed the line of France and Germany in the firm belief that modernization of the country is based on the axis education-researchinnovation." Based on this kind of perspective, research is not doomed to become the poorer sister of the superministry, but rather, "research policy will be the apple of my eye," he says. Berlinguer tives to private societies investing in research and to direct part of the budget to the growth of quality Italian science. hopes to create "a profoundly innovating ministry with reforms directed to increase public and private scientific resources and promote translation of promising discoveries into useful products," and adds that "quality of research has to be evaluated and rewarded properly."

Words like these seem to be revolutionary on the lips of a prominent leftist. Particularly encouraging for many academic scientists are Berlinguer's words on the CRUI document, calling it "a very positive sign" that academics want to reach scientific excellence through cooperative contracts with "advanced" industries. "It is the ministry's intention to invest much in this direction, trying to combine their interests with those of other public scientific bodies such as the National Research Council," he says. Berlinguer also says he is keen to foster proper patenting policies (which have virtually never been considered in Italy) and to promote the creation of academic spinoff enterprises (so far nonexistent on the public research scene).

Furthermore, in an attempt to foster Italy's commitment to research, Berlinguer intends to offer fiscal incen-
Berlinguer hopes to create "a profoundly innovating ministry with reforms directed to strongly increase public and private scientific resources."

"One of my highest goals is to make Italy finally believe that without substantial efforts in this direction, our country won't have any future and will obstruct its full ingress into Europe," he says.

Despite the reassurances to Italy's scientists, none of Berlinguer's words will be easy to translate into action, especially in a time of serious budgetary constraints. But perhaps the biggest challenge facing Berlinguer and his new superministry is not budgetary but social: reconciling the progress of science and the advancement of technology with social equity and a guarantee of equal opportunity to Italy's depressed south. A growing threat of secession on the part of the wealthy north, coupled with the traditional slowness of decision-making, will surely test the new minister's words and resolve in the months ahead.

MARTINA BALLMAIER Milan, Italy

\section{France goes a-sequencing}

A decision to establish a significant genome center in France (Centre de très grand séquençage), capable of sequencing 20 megabases a year, appears to have been made, although there was no formal announcement before Nature Medicine went to press. The proposed center, which could be announced as early as next September, will focus not only on the human genome, but also on the genomes of small organisms, and is expected to rival similar projects in the United Kingdom and the United States. The largest biomedical research institute in France (INSERM), the Centre National de la Recherche Scientifique (CNRS), and an agency supporting agronomic research (INRA), as well as several private companies, will be partners in this project.

The site of the new center has not been chosen, nor has its annual budget been decided. However, Jean Weissenbach, a scientist from the CNRS and currently the Scientific Director for Généthon, a joint venture between the Centre d'Étude du Polymorphisme Humain (CEPH) and the French Muscular Dystrophy Association (AFM), is likely to become the proposed center's first director.

Catherine TASTEMAIN Paris, France 